\section{The antioxidant effects of vitamin C on liver enzymes: aspartate aminotransferase, alanine aminotranferease, alkaline phosphatase and gamma-glutamyltransferase activities in rats under Paraquat insult}

\author{
Benjamin Nnamdi Okolonkwo, \\ Edna Ogechi Nwachuku \\ Department of Medical Laboratory \\ Sciences, Rivers State University \\ of Science and Technology, \\ Nkpolu-Orowuroko, Nigeria
}

\section{Abstract}

Paraquat (PQ) is a bipyridylium herbicide; applied around trees in orchards and between crop rows to control broad-leaved and grassy weeds. Its oxidation results in the formation of superoxides which causes damage to cellular components. In this study, we determined the antioxidant effect vitamin $\mathrm{C}$ has on the liver enzymes [aspartate aminotransferase (SGOT), alanine aminotranferease (SGPT), alkaline phosphatase (ALP), and gamma-glutamyltransferase (GGT)] of rats under this toxic insult. Male rats in groups (A, B, C and D) were intraperitoneally injected with different sublethal increasing doses $(0,0.02,0.04$ and 0.06 $\mathrm{g} / \mathrm{kg}$ body weigh) of $\mathrm{PQ}$ respectively on monthly basis. Subsequently, the subgroups $\left(\mathrm{A}_{2}, \mathrm{~B}_{2}, \mathrm{C}_{2}\right.$ and $\mathrm{D}_{2}$ ) were given orally, $200 \mathrm{mg} / \mathrm{L}$ vitamin $\mathrm{C}$, while the subgroups $A_{1}, B_{1}, C_{1}$, and $D_{1}$, received only water. Four animals per subgroup were decapitated on monthly basis and blood samples taken for enzyme assay. The parameters studied were - SGOT, SGPT, ALP and GGT - liver enzymes. The dose and time dependent $\mathrm{PQ}$ toxicity effect resulted in highly elevated Liver enzymes activities. The subgroups on vitamin $\mathrm{C}$ had significantly lower enzyme activities when compared to the same subgroups on only $\mathrm{PQ}$ insult. But the values were high when compared to the control subgroups $\left(A_{1}\right.$ and $\left.A_{2}\right)$. These results were indication that vitamin $C$ when given at moderate doses and maintained for a longer period could be a life saving adjunct to toxic insult.

\section{Introduction}

Paraquat (PQ), a bipyridylium herbicide that is effective as non-selective herbicide when applied to leaves. ${ }^{1}$ Because Paraquat has a redox potential of $-446 \mathrm{mv}$, any reducing agent with sufficient energy can donate an electron to the bipyridylium divalent cation, Paraquat $^{2+}$, to form a free radical, paraquat ${ }^{+}$. The oxidation of the bipyridylium radical to form the original paraquat ${ }^{2+}$ results in the transfer of the electron to oxygen and the formation of superoxides. ${ }^{2}$ Subsequent HaberWeiss and Fenton reactions yield toxic hydroxyl radicals. Thus the herbicide (paraquat) functions as a catalyst to transfer reducing equivalent to oxygen. These reactive oxygen species (ROS) so formed may escape the electron transport chain and cause damage to cellular components. ${ }^{3}$

In general, Antioxidant systems either prevent these ROS from being formed, or remove them before they can damage vital components of the cell. ${ }^{4}$ Antioxidants are classified into two broad divisions, depending on their solubility in water (hydrophilic) or in lipids (hydrophobic or lipophilic). Water - soluble antioxidants reacts with oxidants in the cell cytosol and the blood plasma, while lipid - soluble ones protects cell membranes from lipid peroxidation. ${ }^{5}$ Though various antioxidants behave synergistically, ascorbic acid (vitamin C) can degrade other antioxidants or reactivate them. ${ }^{5}$ Vitamin C (ascorbate) can directly scavenge oxygen free radicals with and without enzyme catalysts and can indirectly scavenge them by recycling others to their reduced form. ${ }^{6}$ By reacting with activated oxygen more readily than any other aqueous components, vitamin C protects critical macromolecules from oxidative damage. ${ }^{6}$

The relative importance of vitamin $\mathrm{C}$ as an antioxidant is the reason this research was centered on how to enhance the antioxidant system in the body to counter the destructive effects of Paraquat. The liver enzyme was so chosen because the liver is the energy store and source of the body.

\section{Materials and Methods}

\section{Rats}

A total of 100 male albino rats (Rattus norvegicus), weighing between $180-220 \mathrm{~g}$ [average body weight (bw) of $0.2 \pm 0.02 \mathrm{~kg}$ ], obtained from the animal house of the Department of Pharmacology and Toxicology, Collage of Health Sciences, University of Port Harcourt, Choba, Rivers State, Nigeria, were fed ad libitum with animal pelletized finisher feed with negligible vitamin c content, and allowed to acclimatize for two weeks in metabolic cages before the commencement of the study.
Correspondence: Benjamin Nnamdi Okolonkwo, Department of Medical Laboratory Sciences, Faculty of Sciences, Rivers State University of Science and Technology, Nkpolu-Orowuroko, Port-Harcourt, Rivers State, Nigeria.

Tel. +234.805.614.1653.

E-mail: benbruceph@yahoo.com

Key words: Paraquat, antioxidant, vitamin C, reactive oxygen species.

Contributions: BNO, as the lead author, was involved in the research proper, analyzing the samples and making sure that all went well with the study; EON, carried out the statistical analysis and assisted in proof reading of the materials before publication.

Conflict of interests: the authors declare no potential conflict of interests.

Received for publication: 14 February 2013.

Revision received: 6 May 2013.

Accepted for publication: 14 May 2013.

This work is licensed under a Creative Commons Attribution NonCommercial 3.0 License (CC BYNC 3.0).

(C) Copyright B.N. Okolonkwo and E.O. Nwachuku, 2013

Licensee PAGEPress, Italy

Journal of Xenobiotics 2013; 3:e5

doi:10.4081/xeno.2013.e5

\section{Paraquat}

A percentage of $20 \mathrm{w} / \mathrm{v}$ Dizmazone ${ }^{\circledR}$ (Paraquat solution) from Dizengoff W.A. Ltd. (Lagos, Nigeria) sealed in an opaque plastic container, with a shelf-life of two years.

\section{Vitamin C}

Four bottles of Mason Natural ${ }^{\circledR}$ - pure Vitamin C (100 mg) caplets were employed. They are products of Mason Vitamins, Inc. (Miami Lakes, FL, USA).

\section{Method}

Two $\mathrm{mL}$ of sub-lethal doses of the toxicant (PQ) was intraperitoneally (i.p.) administered to the animals, under anaesthetics, ${ }^{7}$ in different dosed subgroups - $A_{1}, A_{2}(0 \mathrm{~g} / \mathrm{kg}) ; B_{1}, B_{2}(0.02$ $\mathrm{g} / \mathrm{kg}) ; \mathrm{C}_{1}, \mathrm{C}_{2}(0.04 \mathrm{~g} / \mathrm{kg})$ and $\mathrm{D}_{1}, \mathrm{D}_{2}(0.06 \mathrm{~g} / \mathrm{kg})-$ on bi-weekly basis over a period of three months (in simulation of contamination from polluted feed, water or air), while the control animals (subgrouped $\mathrm{A}_{1}, \mathrm{~A}_{2}$ ) received $2 \mathrm{~mL}$ of normal saline $(0.98 \%)$ likewise in conformity with international standard in checking injection site reaction. The subgrouped animals were designated into: i) for non vitamin $\mathrm{C}$ treatment; and ii) for vitamin $\mathrm{C}$ treatment as indicated in Table 1.

This study was conducted under eight sub- 
groups $\left(A_{1}, A_{2}, B_{1}, B_{2}, C_{1}, C_{2}, D_{1}\right.$ and $\left.D_{2}\right)$. All the subgroups had 12 animals each with $\mathrm{A}_{1}$ and $\mathrm{A}_{2}$ being the control subgroups that received no Paraquat, $A_{2}, B_{2}, C_{2}$ and $D_{2}$ were placed on vitamin $\mathrm{C}$ - they were made to drink from water bottles with glass sipper tubes that contained vitamin c solution (200 mg/L), $A_{1}, B_{1}, C_{1}$ and $D_{1}$ were the subgroups that received ordinary drinking water with negligible vitamin $\mathrm{C}$ content. The water and vitamin c solution bottles were refilled at least trice daily irrespective of the volume of water or vitamin c remaining in the in-use bottles. It will be note worthy to state that at month 3 , the food and water consumption by the rats were affected by $P Q$ intoxication, mainly the subgroups dosed 0.06 $\mathrm{g} / \mathrm{kg}$ bw without vitamin $\mathrm{c}$ treatment $\left(\mathrm{D}_{1}\right)$.

On monthly intervals, four animals per subgroup were selected, anaesthetized with gaseous isoflurane anesthetic machine, the induction chamber was prefilled with $4 \%$ isoflurane and oxygen $(0.6 \mathrm{~L} / \mathrm{min})$. The rats were placed in the induction chamber and observed for signs of lateral recumbence, (steady breathing and no attempt to right itself when the induction chamber is slightly tilted), only then it becomes anaesthetized enough for transfer to the mask on the rodent breathing circuit. Open the lid of the induction chamber and quickly check for absence of the pedal reflex, ${ }^{8}$ if present, $10 \mathrm{~mL}$ of blood sample were collected using cardiac puncture procedures. ${ }^{7}$
The samples were processed and centrifuge, with the serum separated and labeled accordingly; stored frozen until needed for the estimation of enzyme activity using Kodac Autoanalyser machine. Using the study pattern below, the results were as shown in Tables 1 and 2 and in Figures 1-4.

\section{Animal care}

We do affirm that in carrying out this research that The Nigerian Institutional and National Guide for the care and use of laboratory animals were followed.

\section{Data computation}

The Excel (2007) window's package and two-way analysis of variance (ANOVA) statistical methods were used for the result analysis. With levels of significance measured at $\mathrm{P} \leq 0.05$ and 0.001 , respectively.

Table 1. Treatment chart for the subgroups.

\section{Group A: Control group given $0.0 \mathrm{~g} / \mathrm{kg} \mathrm{PQ}$ and divided into two subgroups}

Al: subsequently received water and feed

A2: subsequently received vitamin $\mathrm{C}$ solution $(1000 \mathrm{mg} / \mathrm{L})$

\section{Group B: Test group given $0.02 \mathrm{~g} / \mathrm{kg}$ PQ and divided into two subgroups}

B1: subsequently received water and feed

B2: subsequently received vitamin C solution (1000 mg/L) and feed

\section{Group C: Test group given $0.04 \mathrm{~g} / \mathrm{kg}$ PO and divided into two subgroups}

$\mathrm{Cl}$ : subsequently received water and feed

C2: subsequently received vitamin C solution $(1000 \mathrm{mg} / \mathrm{L})$ and feed

\section{Group D: Test group given $0.04 \mathrm{~g} / \mathrm{kg}$ PQ and divided into two subgroups}

D1: subsequently received water and feed

D2: subsequently received vitamin C solution (1000 mg/L) and feed

$\mathrm{PQ}$, Paraquat.

Table 2. Values of the enzymes activities within the 3 months.

\begin{tabular}{|c|c|c|c|c|c|c|c|}
\hline Months & $\begin{array}{l}\text { Rat } \\
\text { no. }\end{array}$ & Group & Sub-group & $\begin{array}{l}\text { SGOT } \\
\text { (IU/L) }\end{array}$ & $\begin{array}{l}\text { SGPT } \\
\text { (IU/L) }\end{array}$ & $\begin{array}{c}\text { ALP } \\
\text { (IU/L) }\end{array}$ & $\begin{array}{c}\text { GGT } \\
\text { (IU/L) }\end{array}$ \\
\hline 1 & $\begin{array}{l}4 \\
4 \\
4 \\
4 \\
4 \\
4 \\
4 \\
4\end{array}$ & $\begin{array}{l}\text { A } \\
\text { B } \\
\text { C } \\
\text { D }\end{array}$ & $\begin{array}{l}\mathrm{A} 1 \\
\mathrm{~A} 2 \\
\mathrm{~B} 1 \\
\mathrm{~B} 2 \\
\mathrm{C} 1 \\
\mathrm{C} 2 \\
\mathrm{D} 1 \\
\mathrm{D} 2\end{array}$ & $\begin{array}{c}2.2 \pm 0.4 \\
4.6 \pm 1.1 \\
15.4 \pm 1.2 \\
12.7 \pm 1.9 \\
46.2 \pm 5.6 \\
41.5 \pm 6.7 \\
99.5 \pm 10.1 \\
44.5 \pm 8.9\end{array}$ & $\begin{array}{r}2.52 \pm 0.8 \\
6.50 \pm 0.9 \\
10.95 \pm 2.0 \\
12.53 \pm 2.1 \\
134.88 \pm 23.4 \\
83.87 \pm 15.9 \\
155.67 \pm 36.9 \\
133.23 \pm 28.3\end{array}$ & $\begin{array}{c}11.25 \pm 3.0 \\
14.72 \pm 1.9 \\
53.44 \pm 11.2 \\
33.94 \pm 8.5 \\
82.00 \pm 17.5 \\
20.83 \pm 3.2 \\
318.17 \pm 39.0 \\
272.00 \pm 46.1\end{array}$ & $\begin{array}{l}13.63 \pm 3.8 \\
12.17 \pm 2.6 \\
32.00 \pm 5.6 \\
22.33 \pm 3.3 \\
42.67 \pm 9.9 \\
26.33 \pm 5.5 \\
65.00 \pm 13.7 \\
35.50 \pm 4.7\end{array}$ \\
\hline 2 & $\begin{array}{l}4 \\
4 \\
4 \\
4 \\
4 \\
4 \\
4 \\
4\end{array}$ & $\begin{array}{l}\text { A } \\
\text { B } \\
\text { C } \\
\text { D }\end{array}$ & $\begin{array}{l}\mathrm{A} 1 \\
\mathrm{~A} 2 \\
\mathrm{~B} 1 \\
\mathrm{~B} 2 \\
\mathrm{C} 1 \\
\mathrm{C} 2 \\
\mathrm{D} 1 \\
\mathrm{D} 2\end{array}$ & $\begin{array}{c}5.6 \pm 1.3 \\
6.2 \pm 1.2 \\
19.8 \pm 4.7 \\
15.1 \pm 1.3 \\
94.7 \pm 11.8 \\
74.3 \pm 13.0 \\
138.5 \pm 22.3 \\
107.6 \pm 18.9\end{array}$ & $\begin{array}{r}4.18 \pm 2.7 \\
6.25 \pm 2.4 \\
41.15 \pm 4.4 \\
31.14 \pm 6.3 \\
147.00 \pm 15.2 \\
96.25 \pm 11.8 \\
258.75 \pm 31.9 \\
142.00 \pm 34.2\end{array}$ & $\begin{array}{c}15.70 \pm 0.5 \\
7.38 \pm 2.8 \\
100.30 \pm 10.0 \\
71.74 \pm 15.4 \\
130.68 \pm 8.4 \\
82.33 \pm 27.6 \\
315.53 \pm 16.34 \\
185.18 \pm 6.5\end{array}$ & $\begin{array}{l}13.33 \pm 1.7 \\
13.51 \pm 7.0 \\
63.00 \pm 13.9 \\
36.88 \pm 3.0 \\
76.25 \pm 13.0 \\
35.13 \pm 2.2 \\
99.00 \pm 6.0 \\
76.00 \pm 11.3\end{array}$ \\
\hline 3 & $\begin{array}{l}4 \\
4 \\
4 \\
4 \\
4 \\
4 \\
4 \\
4\end{array}$ & $\begin{array}{l}\text { A } \\
\text { B } \\
\text { C }\end{array}$ & $\begin{array}{l}\mathrm{A} 1 \\
\mathrm{~A} 2 \\
\mathrm{~B} 1 \\
\mathrm{~B} 2 \\
\mathrm{C} 1 \\
\mathrm{C} 2 \\
\mathrm{D} 1 \\
\mathrm{D} 2\end{array}$ & $\begin{array}{c}4.2 \pm 0.9 \\
6.8 \pm 3.4 \\
54.1 \pm 8.0 \\
48.3 \pm 5.5 \\
115.2 \pm 20.0 \\
101.5 \pm 5.5 \\
342.0 \pm 18.7 \\
199.0 \pm 18.1\end{array}$ & $\begin{array}{c}1.35 \pm 0.6 \\
7.50 \pm 1.2 \\
99.00 \pm 1.0 \\
46.50 \pm 3.5 \\
191.00 \pm 24.0 \\
74.50 \pm 10.5 \\
167.50 \pm 12.5 \\
58.00 \pm 6.0\end{array}$ & $\begin{array}{r}19.60 \pm 0.2 \\
13.53 \pm 1.5 \\
1028.00 \pm 44.2 \\
527.50 \pm 35.1 \\
1297.00 \pm 47.9 \\
691.00 \pm 55.8 \\
1570.00 \pm 68.0 \\
1096 \pm 37.7\end{array}$ & $\begin{array}{r}12.75 \pm 0.8 \\
11.60 \pm 1.8 \\
87.00 \pm 13.0 \\
50.00 \pm 21.0 \\
128.50 \pm 8.5 \\
56.50 \pm 3.5 \\
170.00 \pm 6.4 \\
125.00 \pm 12.0\end{array}$ \\
\hline
\end{tabular}

SGOT, aspartate aminotransferase; SGPT, alanine aminotranferease; ALP, alkaline phosphatase; GGT gamma-glutamyltransferase. 


\section{Results}

The SGOT activity of all the subgroups is shown in Figure 1. The enzyme activity values was found to have increased on the test subgroups $\left(\mathrm{B}_{1}, \mathrm{~B}_{2}, \mathrm{C}_{1}, \mathrm{C}_{2}, \mathrm{D}_{1}\right.$ and $\left.\mathrm{D}_{2}\right)$ when compared to the control subgroups $\left(\mathrm{A}_{1}\right.$ and $\left.\mathrm{A}_{2}\right)$. And the increases was found to be directly related to the dose and exposure time effects $(\mathrm{P} \leq 0.001)$. As the time of exposure moved from month 1 down to month 3 the enzyme activity of the $P Q$ only treated subgroups $\left(B_{1}\right.$, $\mathrm{C}_{1}$ and $\mathrm{D}_{1}$ ) increased two- to three-folds that of the subgroups that received vitamin $\mathrm{C}$ in addition to $P Q$ insult $\left(B_{2}, C_{2}\right.$ and $\left.D_{2}\right)$ at the same level of significance $(\mathrm{P} \leq 0.001)$. indicating that an interaction exists between dose of $\mathrm{PQ} /$ vitamin $\mathrm{C}$ given and time of exposure.The test subgroups with the highest dose $0.06 \mathrm{~g} / \mathrm{kg}$ bw $\left(D_{1}\right.$ and $D_{2}$ ) gave an explicit picture on how vitamin c effected an improved enzyme activity when compared to the one on PQ insult only. With $D_{1}$ being higher than two-times $D_{2}$ at months 1 and 3 .

The results of the SGPT enzyme activity values as shown in Figure 2 were similar to the ones obtained in SGOT (Figure 1) values above. There existed an interaction between dose given and time of exposure effects at $\mathrm{P} \leq 0.001$ level of significance. The test subgroups $\left(B_{1}, B_{2}, C_{1}, C_{2}, D_{1}\right.$ and $\left.D_{2}\right)$ were highly elevated when compared to the control subgroups $\left(A_{1}\right.$ and $\left.A_{2}\right)$ from month 1 to month 3 especially the subgroups dosed $0.04 \mathrm{~g} / \mathrm{kg}$ and $0.06 \mathrm{~g} / \mathrm{kg} \mathrm{bw}\left(\mathrm{C}_{1}, \mathrm{C}_{2}, \mathrm{D}_{1}\right.$ and $\mathrm{D}_{2}$ at month 1$)$ and $\left(\mathrm{B}_{1}, \mathrm{~B}_{2}, \mathrm{C}_{1}, \mathrm{C}_{2}, \mathrm{D}_{1}\right.$ and $\mathrm{D}_{2}$ at months 2 and 3 ). The within group comparison indicated a well defined reduction in the values of the SGPT enzyme activity of the vitamin $c$ treated subgroups $\left(\mathrm{B}_{2}, \mathrm{C}_{2}\right.$ and $\left.\mathrm{D}_{2}\right)$ when compared to the subgroups on $\mathrm{PQ}$ insult only $\left(\mathrm{B}_{1}, \mathrm{C}_{1}\right.$ and $\left.\mathrm{D}_{1}\right)$ from month 1 to month 3 . This results was in line with the results of the SGOT enzyme activity values obtained in Figure 1, showing that vitamin $\mathrm{c}$ has an ameliorative effect on intracellular PQ toxicity.

The results obtained from ALP enzyme activity on the subgroups were quite remarkable. At month 1 , the test subgroups with lower doses of $\mathrm{PQ}\left(\mathrm{B}_{1}, \mathrm{~B}_{2}, \mathrm{C}_{1}\right.$ and $\left.\mathrm{C}_{2}\right)$ showed slight elevation of ALP activity when compared to the control subgroups $\left(A_{1}\right.$ and $\left.A_{2}\right)$ at $P \leq 0.05$, while the subgroups that received the highest dose of $0.06 \mathrm{~g} P \mathrm{PQ} / \mathrm{kg}$ bw $\left(\mathrm{D}_{1}\right.$ and $\left.\mathrm{D}_{2}\right)$ had an elevated ALP activity at $\mathrm{P} \leq 0.01$ when compared to the control subgroups. As the time of exposure increased from month 1 to month 3 the level of enzyme activity of the test subgroups increased the more to a level that was quite high at month $3(\mathrm{P} \leq 0.001)$. In all this, we found out that the vitamin $c$ treated test sub- groups had lower ALP enzyme activity values than the subgroups under the same $P Q$ insult only (B2<B1, C2<C1, D2 $<\mathrm{D} 1)$ at $\mathrm{P} \leq 0.05$ (month 1), $\mathrm{P} \leq 0.01$ (month 2) and $\mathrm{P} \leq 0.001$ (month 3) respectively. This result showed that an interaction existed between the dose of $\mathrm{PQ}$ given and time of exposure of the toxic insult, and also there was a relationship between the effect of the vitamin $c$ given with the dose of $P Q$ given and the time of exposure.

At month 1 the GGT enzyme activity values of the test subgroups were increasing in direct relation to the increase in dose of the toxicant (PQ) at $\mathrm{P} \leq 0.001$, and this relationship continued to increase the enzyme activity even as the exposure time increased from month 1 to month 3 at $P \leq 0.001$. Also the vitamin $c$ treated subgroups $\left(B_{2}, C_{2}\right.$ and $\left.D_{2}\right)$ all had much lower enzyme activity values than their conterpart under $\mathrm{PQ}$ insult only $\left(\mathrm{B}_{1}, \mathrm{C}_{1}\right.$ and $\left.\mathrm{D}_{1}\right)$ at $\mathrm{P} \leq 0.001$ from month 1 through to month 3 . This also suports the existence of an interaction between the dose of $P Q$ given and time of exposure of the toxic insult, and also a rela-

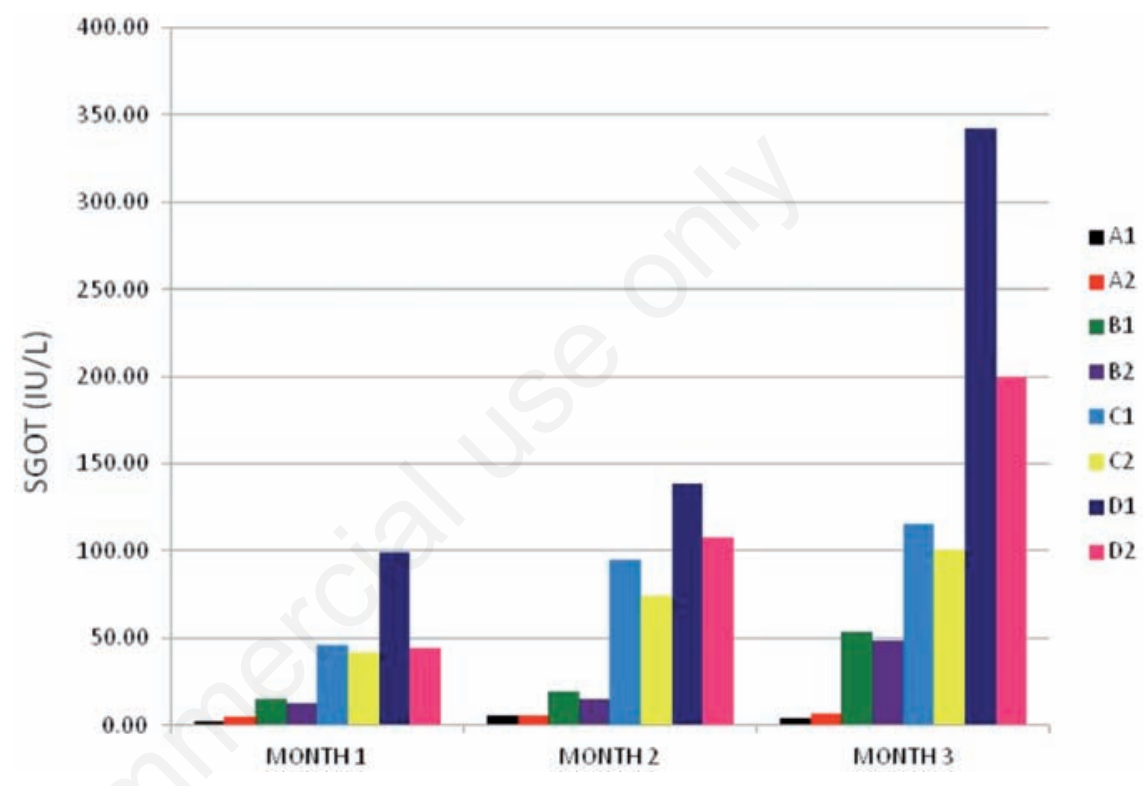

Figure 1. Aspartate aminotransferase (SGOT enzyme) activity values for 3 months study period.

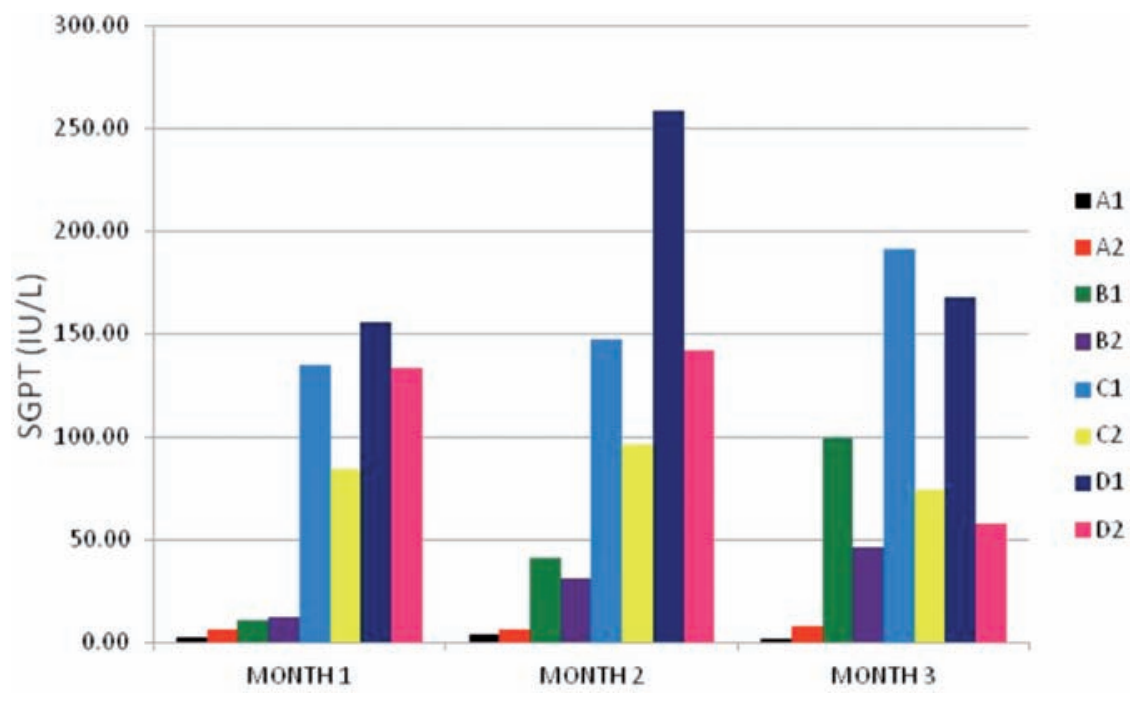

Figure 2. Alanine aminotranferease (SGPT enzyme) activity values for 3 months study period. 
tionship between the effect of the vitamin c given with the dose of $P Q$ given and the time of exposure.

\section{Discussion}

PQ studies and the toxicity effects of this chemical on the organs of the body, including its mechanism of toxicity have been reported. ${ }^{9}$ Furthermore, several reports presented $P Q$ as a hepatotoxin. ${ }^{10-13}$

Following the findings from the acute toxicity study, where it was observed that toxicity effects existed with increasing dose and time of exposure of $\mathrm{PQ}$ (i.p.) insult on the liver cells. ${ }^{14} \mathrm{~A}$ chronic study was designed to assess the toxicity of $\mathrm{PQ}$ at long duration (3 months) and also to find the possibility of ameliorating the toxicity effects using antioxidant (vitamin C).

From the liver enzymes - SGOT, SGPT, ALP and GGT - results obtained, all had changes that were highly significant $(\mathrm{P} \leq 0.001)$ both within and between subgroups (Table 2 and Figures 1-4), and these changes were all dose and exposure-time dependent. The enzymes activity values of the subgroups that received $\mathrm{PQ}$ only were almost two to five folds increased compared to that of the subgroups that received vitamin $\mathrm{C}$ in addition to the $\mathrm{PQ}$ insult. SGOT values of vitamin $\mathrm{C}$ treated subgroups where significantly lower than those on $P Q$ insult only $\left(\mathrm{B}_{2}<\mathrm{B}_{1}, \mathrm{C}_{2}<\mathrm{C}_{1}\right.$, and $\mathrm{D}_{2}<\mathrm{D}_{1}$ from

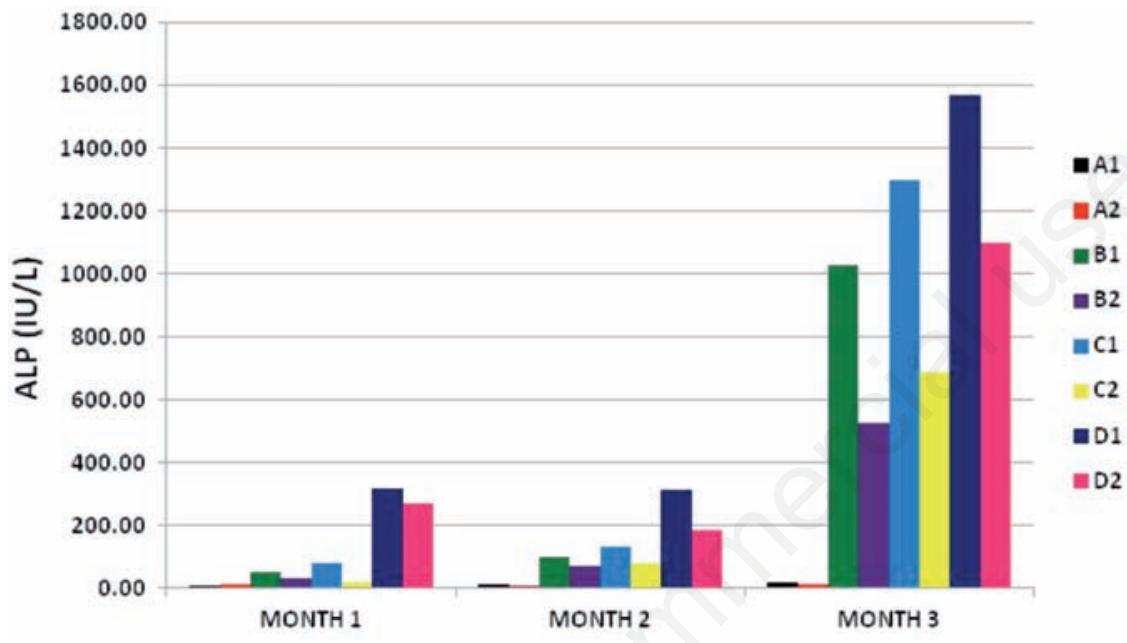

Figure 3. Alkaline phosphatase (ALP enzyme) activity values for 3 months study period.

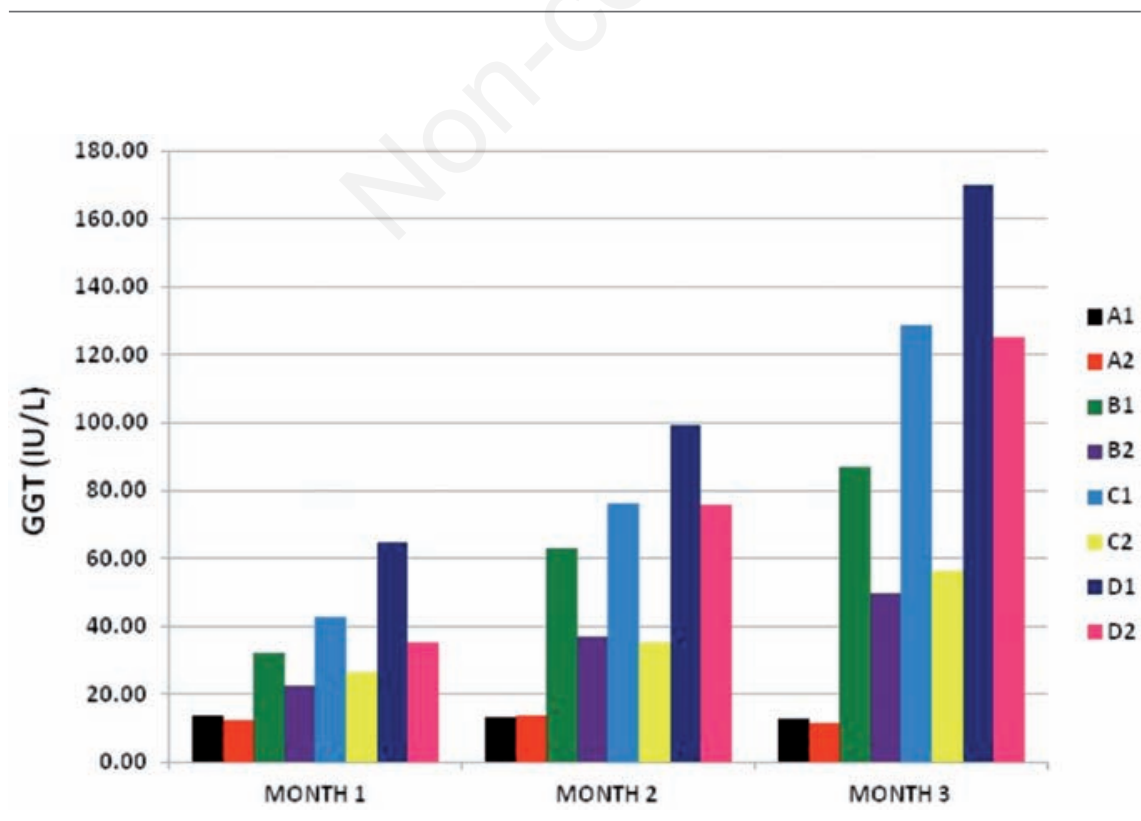

Figure 4. Gamma-glutamyltransferase (GGT enzyme) activity values for 3 months study period. month 1 to month 3 (Figure 1) except the control group $\mathrm{A}$, in-which the vitamin $\mathrm{C}$ treated subgroup $\left(\mathrm{A}_{2}\right)$ had slightly elevated SGOT values throughout the three months than the subgroup without vitamin $C$ and $P Q\left(A_{1}\right)\left(A_{1}<A_{2}\right)$. These changes were also observed in the values of other enzymes - SGPT, ALP and GGT (Figures 2-4).

It has been shown that $P Q$ toxicity initiates lipid peroxidation which causes toxic destruction of lipid membrane bilayers initiating release of membrane bound enzymes - SGPT, ALP and GGT - to the cytoplasm. ${ }^{15-18}$ This explains the highly elevated values of these enzymes in $P Q$ only treated subgroups $\left(B_{2}, C_{1}\right.$ and $\mathrm{D}_{1}$ ) as compared to the subgroups that received, in addition to $P Q$ insult, vitamin $C$ $\left(\mathrm{B}_{2}, \mathrm{C}_{2}\right.$, and $\left.\mathrm{D}_{2}\right)$ in Figures 2-4. Indicating that vitamin $\mathrm{C}$, to a large extent, reduced the toxic insults $^{6}$ and acted as a substrate for the antioxidant enzyme ascorbate peroxidase, a function that is particularly important in stress resistance, ${ }^{19}$ thereby maintaining and repairing cellular integrity and function ${ }^{15-17}$ which led to the lowered values obtained in $\left(\mathrm{B}_{2}, \mathrm{C}_{2}\right.$ and $\left.\mathrm{D}_{2}\right)$ as seen in Figures 2-4.

Generally, there was an improvement in enzyme activity in the subgroups on vitamin $\mathrm{C}$ during the $P Q$ toxic insult $\left(B_{2}, C_{2}\right.$, and $\left.D_{2}\right)$ in Figures 1-4. Though these values were still high when compared to the control subgroups $\left(A_{1}\right.$ and $A_{2}$ ) and above the reference values for rat's liver enzymes, it's still a pointer to health improvement. These shows that if vitamin $\mathrm{c}$ treatment was continued for a longer period it could have totally repaired the liver cells and improve the health status of the animals.

\section{Conclusions}

The result of this study has demonstrated that vitamin $\mathrm{c}$ has the capacity to improve the health status of animals under toxic insult. Exposure of rats to $\mathrm{PQ}$ induced a highly elevated liver enzyme - SGOT, SGPT, ALP and GGT activities that were dose and time dependent, which on subsequent administration of vitamin $\mathrm{C}$ a reduction in the activity levels were observed throughout the study, indicating the reliability of vitamin $\mathrm{c}$ as an adjunct to the treatment of a toxic insult.

\section{Recommendation}

Vitamin C, a potent antioxidant should be one of the first line treatments (emergency procedure) for toxic insult. Vitamin $\mathrm{C}$ administration in PQ toxicity should not be ignored, and it should be extended even after patient's 
recovery for adequate intracellular repairs to be achieved.

\section{References}

1. Mees GC. Experiments on the herbicidal action of 1, 1'-ethylene- 2, 2'- dipyridylium dibromide. Ann Appl Biol 1960;48:601-12.

2. Punchard NA, Kelly FJ. Free radicals: a practical approach. 0xford: 1RL press; 1996.

3. Davies K. Oxidative stress: the paradox of aerobic life. Biochem Soc Symp 1995; 61:1-31.

4. Rhee SG. Cell signaling. H202, a necessary evil for cell signaling. Science 2006;312:1882-3.

5. Sies H. Oxidative stress: oxidants and antioxidants. Exp. Physiol 1997;82:291-5.

6. Asada K. Ascorbate peroxidase - hydrogen peroxide scavenging enzyme in plants. Physiol Plant 1992;85:235-41.

7. Animal Care and Ethics Committee. Blood collection in rodents and rabbits. Newcastle: University of Newcastle, ACEC;
1999. Available from: http:/www.newcastle.edu. au/research/animal/revision/acec 29.pdf Accessed: June 2007.

8. Diel KH, Hull R, Morton D, Pfister R, Rabemampianina Y, Smith D, et al. A good practice guide to the administration of substances and removal of blood including routes and volumes. J Appl Toxicol 2001; 21:15-23.

9. Bus JS, Cogen SZ, Olgaard M, Gibson JE. A mechanism of paraquat toxicity in mice and rats. Toxicol Appl Pharmacol 1976;35: 501-13.

10. Clark DG, McElligott TF, Hurst EW. The toxicity of paraquat. Br J Ind Med 1966;23: 126-32.

11. Gibson JE, Cagen SZ. Paraquat - induced functional changes in kidney and liver. In: Wong, RC, Stevens, JB, eds. Biochemical mechanisms of paraquat toxicity. 2nd ed. New York: Academic Press; 1977. pp 117-136.

12. Cagen SZ, Janoff AS, Bus JS, Gibson JE. Effect of paraquat (methylviologen) on liver function in mice. $\mathrm{J}$ Pharmacol Exp Ther 1976;198:222-8.

13. Murray RE, Gibson JE. A comparative study of paraquat intoxication in rats, guinea pigs and monkeys. Exp Mol Pathol 1972;17:
317-25.

14. Dede EB, Okolonkwo BN, Ngokere AA. Toxicological effect of paraquat on the histology of the stomach, small Intestine and testis of male albino rats (Rattus rattus). Port Harcourt Med J 2007;2:51-5.

15. Wefers H, Sies H. The protection by ascorbate and glutathione against microsomal lipid peroxidation is dependent on vitamin E. Eur J Biochem 1988;174:353-7.

16. Wershana KZ. The influence of vitamin C or selenium on paraquat induced toxicity in Guinea Pigs. Pak J Biol Sci 2001;4:81-8.

17. Tantcheva LP, Stoeva ES, Galabov AS, Braykova AA, Savov VM, Mileva MM. Effect of vitamin $E$ and vitamin $C$ combination on experimental influenza virus infection. Exp Clin Pharmacol 2003;4:259-64.

18. Hassan HM, Fridovich I. Superoxide dismutases: detoxication by a free radical. In: WB Jakoby, ed. Enzymatic basis of detoxication. New York: Academic Press; 1980. pp 311-322.

19. Shigeoka S, Ishikawa T, Tamoi M, Miyagawa Y, Takeda T, Yabuta Y, et al. Regulation and function of ascorbate peroxidase isoenzymes. J Exp Bot 2002;53: 1305-19. 